\title{
Development Status and Path Research of Chinese Implantable Advertisement
}

\author{
Wenqing Wei \\ School of Design Art, Jingdezhen Ceramic Institute \\ Jingdezhen City, Jiangxi Province, China \\ 105186977@qq.com
}

Keywords: Implantable advertising; Advantages; Current situation; Problems; Measures

\begin{abstract}
Currently, the development of China's advertising industry market are prosperous, therefore, to find a new way of advertising to attract people become the current imminent task for advertisers. Implantable advertising as a new trend widely exists in a variety of film and television works, quietly walked into our sight in a silent way. Throughout the development of implantable ads in China, it is in the early stages of development, and there are still many obstacles and drawbacks. This paper mainly discusses the development of implantable advertising in the Chinese market, analyzing its existing problems in the process of development and puts forward the corresponding measures to solve these problems.
\end{abstract}

\section{The Meaning of Implantable Advertising}

Implantable advertising is called implantable marketing, can also be understood as a soft ad or hidden advertising, referring to that the product or brand and its representative visual symbols and services are quietly implanted in a variety of media including movies, TV shows, television shows, newspapers, magazines, online games, cell phone messages and other carriers, through scene reproduction of the brand or product, so that when the audience receive the media information, at the same time, they can unknowingly leave the impression on the product and brand, and then to achieve the purpose of marketing.

\section{The Advantages of Implantable Advertising}

With the development of commodity economy, the market competition is becoming more and more intense. More and more producers and operators need to carry out the promotion of goods by means of advertising. The implantable advertisement is favored by advertisers because of its unique personality. The wide application of this method is also due to the following advantages.

\section{Implantable Advertising Involves a Wide Range of People}

Implantable advertising is called "silent sellers", it involves a wide range of people. These include viewers who love movies, TV shows, comedy and entertainment programs, as well as those who love online games and use video software to watch movie, almost everything is "brand", it have many times to contact with the audience, the scope is also the most extensive.

\section{Delivery of the Ads to Audiences in the Unconscious State}

In the era of this ads flying, when a variety of advertising are overwhelming and coming, the consumer's resistance emotion to ads is very large. At this point, the implantable advertising as a new form of advertising are quietly implanted into the film, television, network and other media, subtly transmit advertising information to consumers.

\section{Implantable Advertising is not Negligible}

In the implantation of advertising, the product is an indispensable part of the film and television works, in which we can see the emergence of many brands, due to the randomness of these implantable ads, and the relevance of product and the plot is very good, Less subject to the contradict and rejection. Especially when the masses sit in the cinema or use video software to watch the film and television works when they have to accept the ads in front of the play. So that the implantable ads have a non-negligibl 


\section{The Development Status Quo of China's Implantable Advertising}

The development of implantable advertising in the West has been a hundred years of history, but in China it started rather late. But it did not affect its pace of development, from the current progress of development, television, film, television and network technology, we can see the shadow of implanted advertising.

\section{The Implantable Advertising in TV Shows and Films}

In recent years, implantable advertising often appear by treating the modern life as a carrier in the drama. Such as: the ZTE mobile phone, Samsung computer, Erie nutrition Shuhua milk and Yibao pure water in "Beijing Youth". The Jingdong Mall, ASUS notebook, Happy etc., in "Love Apartment 4". China's film implantation ads appeared in the 90s of last century, from the implantable advertising in the first film of Feng Xiaogang's "Endless", after that, the film implanted the rise rapidly like mushrooming. Recently, from the hot movies, we can see the familiar brands such as: the Lenovo notebook, Le Méridien, Sina microblogging, Founder Securities, China Unicom 3G Wo in "Thai Jiong". Piaget Jewelry, Lenovo, Minsheng Bank line card, Chanel, Hermes package and others in "Beijing Met Seattle".

\section{The Implantable Advertising in Television Programs}

Nowadays, it is also very common that advertising is planted in TV programs, especially CCTV Spring Festival Evening, implantation is more serious, such as: Sohu, Guojiao, Sanya tourism in "Donations". Huiyuan juice in "Liu Qian Magic". The Infiniti car, the famous 999 cold spirit in "Where is the father", of course, the naming advertising is one of them, such as Jiaduobao in China's Good Voice and so on.

\section{The Implantable Advertising in Network Technology}

With the development of Internet technology, implantable advertising presents a variety of forms. Implantation of advertising in the official microblog, such as Liu Xiang London Olympic Games print ads for Nike. The major video portals are implanted the advertisements such as the implantable ads in Qiyi and Youku video buffering time.

\section{The Existing Problems in Chinese Market Implantable Advertising}

\section{Low Product Brand Recognition}

Product is an indispensable part of the storyline in the film and television works, it must have a better identification. Therefore, the implantable ad is only suitable for some familiar brands. The audience accurately identify the goods brand and information in a short few seconds. However, for some strange brands, it is difficult for them to achieve this effect, in the twinkling of an eye the information was forgotten by the audience. Therefore, the brand having a high visibility and awareness are the primary condition of implantable advertising. At the same time it is not suitable for deep persuasion, if forced to tell, it will undermine the whole story and even the entire film and television works, and even the contradict mood of audience will appear.

\section{The Convergence of Product and the Plot of is not Natural or Clever}

Most of the product brands appear in movies, TV shows, in short, it just offers an opportunity to meet with the audience. However, some advertisers in order to pursue economic interests, adding a lot of the product having nothing to do with the development of stories in the play, which appears to be too far-fetched, lack of creativity and their relevance is not strong. Even in some dramas, the actors are asked to read the name of the goods more straightforward, advertising is too obvious, not natural or clever. In this way, the implantation of advertising can not quietly leave a deep impression to the audience, do not achieve the intention of implantation.

The Contradiction between Business and Art Led to the Contradiction between Producers and Advertisers

The commercial and artistic nature of a film and television work have always been an irreconcilable contradiction, which makes it difficult for producers and advertisers to reach a consensus. On the one hand, advertisers think they give money, hopes to show their product image and product identification in the picture as much as possible, do not consider whether this has artistic effect. 
On the other hand, the director is not a marketing expert, they often do not tailor a plot for product, the final result is: the lack of content, in order to advertising, combine the story together stiffly. This seriously damages the overall effect of the film plot.

There is a Big Financial Risk in Implantable Advertising

Implantable advertising actually exist a lot of financial risk, many advertisers worry about that their investment will be lost because the film being used is not a good selling market or not released. It is justified that they are worried. Very often, because the reviews do not pass or the relevant lens was screened off or the film failed to issue within the scope of the package, then the investment of the sponsorship is likely to have no return or even crop failure.

\section{Implantable Advertising Development Countermeasures in China}

In view of the above problems, on China's implantable advertising development strategy, I think we can discuss and think from the following aspects:

\section{Fully Consider the Brand's Suitability, Rationally Choose Implant Advertising}

Implantable advertising as a new way of information transmission, but this does not mean that any kind of brand can get very good results through this method. Therefore, in the implantation of advertising, we need to fully consider the brand and the characteristics of the product itself, rationally choose. Implantable advertising has a hidden feature, this implantation is more suitable for some brands with suitable stage of development and having a certain reputation and awareness, it is not suitable for the fresh brand just entering the market. Because when the brand is in the bud stage, the consumer will be unfamiliar with the product, will not pay attention to this, even with the product forgotten in the pan of the flash. However, when the brand is mature and has deepened the hearts of consumers, it can be using the way of advertising so that consumers deepen the impression and understanding of the product, thus promoting the desire to buy.

\section{Implanting in a Natural, Clever, Harmonious Way, Refuse to Advertise Directly}

A really good hidden ad is the perfect combination of the story and the product, it does not necessarily show the product brand logo and promote its product characteristics, but to allow consumers to be impacted in the absence of unconscious, the audience accept it and produce interest without any worry, and produce a profound impression. Consumers like to accept the things in their own deliberate judgments, and do not like too straightforward inculcation. So the implantable advertising should consider the expression of "Wind into the night, moistening things silently" in oeder to win the favor of consumers.

\section{Advertising Products Serve the Story, Coordinate the Relationship Between the two Sides}

The difficulty of implantable advertising is that it needs to meet the requirements of the story and marketing simultaneously, if we accommodate the plot too much, which easily affect the quality of advertising communication, if prominent advertising too much, will be overwhelming the plot, implantable advertising survive in this gap. In this case, it needs the sponsor, screenwriter and director to fully communicate with each other, to understand and coordinate the relationship between the two sides, the less the traces of advertising and plot with the more natural, then the effect of spread will be naturally better, The formation of the brand needs to rely on the continuous dissemination and promotion of advertising, only through repeated flash, we can make consumers have the impression, treating the implantation of advertising as a form of support, the product can't be above the works, it must serve the plot, character. Do not reveal the traces and not be ignored. So that the story and product promotion really achieve a win-win situation.

\section{Establish and Improve the Implantable Advertising Agency Mechanism}

To gradually establish an implantable advertising agency mechanism. This can give full play to the role of the bridge of agents, while it can be appropriate to reduce the risk of advertising funds through agents, and even transfer the partial risk of advertising to a strong agent, so that the implantable advertising industry can get more healthy and sustainable development. 


\section{Implantable Advertising needs to Grasp the "Degree", Infecting Audience with the Brand Personality}

Implantable ads must first be based on life, once out of life, it will cause the consumer's inversion and thus affect the effect of implantation. The use of implantable advertising must first adhere to the story in the first place, advertising can not affect the smooth and completion of the story, so that advertising is overwhelming. Implant should be aware of the degree, do not repeat the ads or shouting slogans to instill the audience, not cause the audience's resentment too much, in the subconscious let them accept, to enhance the memory, transmit brand personality with emotion, infecting the audience, triggering their curiosity, and then promoting the purchase.

\section{Pay Attention to Listen to the Feedback of Consumers}

The ultimate goal of advertising is to let the public accept the product brand, implantable advertising is a means of marketing, while consumers are its target population. It is therefore important to listen to the consumer's feedback after implanting the ads. Of course, feedback has a variety of forms, it can be market research, issue questionnaires, street visits or using the network or cell phone text messages and other means to carry out investigation. Although the survey results can not cover all the views, but the advertisers can also learn from the success of the implantable ads.

\section{Conclusion}

Implantable advertising has entered the period of rapid development, it is in the rising stage, has great potential, and the advantage is quite obvious. As a new way of marketing, it is the marriage of business and film and television works. The insertion of product information and service advertising in which will be subtly instilled brand image in the vast number of consumers, I believe under the situation of the laws and regulations and marketing model gradually being improved and mature, implantable advertising will have a good development prospect.

\section{References}

[1] T. Xu. Interpreting the implantation of advertising from the perspective of film and television works [J]. Southeast Propagation, 2009 (12).

[2] Y.L. Cai, X.N. Feng. Chevrolet by the occasion of "Transformers 3" to create a new model of implantable advertising [J]. Jiangsu Business, 2012 (12).

[3] M. Huang. The win-win implantable advertising strategy in TV program [J]. Digital Fashion (New Visual Arts), 2012 (5).

[4] Z. Hao. Discussion on the existence problems of implantable advertising and countermeasures [J]. Economist, 2013. 